\title{
Seroprevalence of Bovine Parainfluenza Virus Type 3 (bPI-3V) in Ruminants from Grenada
}

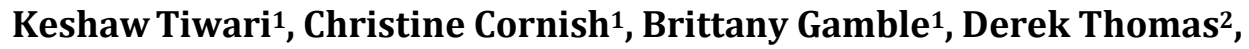 \\ Ravindra Nath Sharma ${ }^{{ }^{*}}$ \\ ${ }^{1}$ Department of Pathobiology, School of Veterinary Medicine, St. George's University, St. George's, Grenada \\ ${ }^{2}$ Ministry of Agriculture, Land, Forestry, Fisheries and Environment, Government of Grenada, West Indies \\ Email: "rsharma@sgu.edu
}

Received 18 January 2016; accepted 14 February 2016; published 18 February 2016

Copyright (C) 2016 by authors and Scientific Research Publishing Inc.

This work is licensed under the Creative Commons Attribution International License (CC BY).

http://creativecommons.org/licenses/by/4.0/

(c) () Open Access

\section{Abstract}

Respiratory viral infections are known for serious economic losses in ruminants. Bovine parainfluenza 3 virus (bPI-3V) a member of Respirovirus genus in association with other respiratory viruses causes respiratory disease complex in ruminants. The aim of this study was to estimate the seroprevalence of bPI-3V in non vaccinated cattle, sheep and goats from Grenada. Sera were collected randomly from 60 sheep, 60 goats and 60 cattle from all six parishes of Grenada. Sera were tested for antibodies to bPI-3V using an indirect Enzyme Linked Immunosorbant Assay (ELISA) kit. Antibodies to bPI-3V were detected in 13.4\% (Confidence Level (CL): 95\%; Confidence Interval (CI): $4.76 \%$ to $22.02 \%$ ) in cattle; $16.7 \%$ (CL: $95 \%$; CI: $7.26 \%$ to $26.14 \%$ ) in sheep and $11.7 \%$ (CL: 95\%; CI: $3.57 \%$ to $19.83 \%$ ) in goats. There was statistically no significant difference in prevalence $(p>0.05)$ of antibodies to bPI-3V in cattle, sheep and goats in Grenada. This is the first report on seroprevalence of bPI-3V in ruminants in Grenada, West Indies.

\section{Keywords}

Grenada, Bovine Parainfluenza-3 Virus, Seroprevalence, Ruminants

\section{Introduction}

Bovine Parainfluenza-3 virus (bPI-3V) is in the genus Respirovirus of the subfamily Paramyxovirinae, order Mononegavirales, of the family Paramyxoviridae. The genus Respirovirus also includes the genetically and an-

\footnotetext{
*Corresponding author.
}

How to cite this paper: Tiwari, K., Cornish, C., Gamble, B., Thomas, D. and Sharma, R.N. (2016) Seroprevalence of Bovine Parainfluenza Virus Type 3 (bPI-3V) in Ruminants from Grenada. Open Journal of Veterinary Medicine, 6, 23-27. 
tigenetically related human parainfluenza viruses types 1 and $3\left(\mathrm{hPI}_{1} \mathrm{~V}\right.$ and $\left.\mathrm{hPI}_{3} \mathrm{~V}\right)$ [1]. RNA of bPI-3V is single and continuous with a molecular weight of $4.5 \times 10^{6}$ Daltons [2]. Various genotypes of the bPI-3 virus have been identified. Harwood et al. [3] proposed 2 distinct bPI-3 V genotypes (bPI-3Va and bPI-3Vb). The virulence of the virus varies with different isolates.

Respiratory viral infections cause serious economic losses in ruminants. It has been reported that bovine parainfluenza virus (bPI-3V), bovine respiratory syncytial virus (BRSV), and bovine herpes virus-1 (BHV-1) are the main viral etiological agents involved in respiratory disease complex in ruminants. Along with bacteria and Mycoplasma these viruses cause serious illness. Clinical disease in small and large ruminants is usually mild, with symptoms of fever, nasal discharge and cough. Complications occur with co-infection of other respiratory viruses due to immunosuppressive effects of bPI-3V [1].

The bPI-3V infects both large and small ruminants and is transmitted primarily by droplets. Cross transmission can also occur among these species.

The bPI-3V was first isolated in the United States in 1959 from dairy cattle [4]. Following this study, Abinanti et al. [5] reported bPI-3 antibodies in a wide geographical distribution in cattle in the USA. bPI-3V has been recognized to be endemic in beef and dairy cattle populations in Europe, Asia, Africa and North and South America. Reports of bPI-3 infection in bovines are available from Nigeria [6], Turkey [7] [8], India [9], Canada [10], Iran [11] [12], Lithuania [13], Saudi Arabia [14] [15], Mexico [16] [17], Brazil [18], Syria [19] and France [20].

Limited reports are available on bPI-3V infection in small ruminants. Available reports are from Egypt [21], Romania [22], Turkey [23] [24], Canada [25], Brazil [18] and Japan [26].

Grenada is the southernmost island country in the southeastern Caribbean Sea, with an area of approximately $348.5 \mathrm{~km}^{2}$ and a population estimated at 100,000. The country consists of 6 parishes. The country with low hills, small trees and shrubs, and tropical climate is most suitable for small ruminant production. Sheep and goats are kept for meat and milk. Estimated population size is 3000 sheep, 2500 goats and 1500 cattle in Grenada (Dr. Bowen Louison, Chief Veterinary Officer, Ministry of Agriculture, Land, Forestry, Fisheries and Environment: personal communication). Cattle in Grenada are kept for meat purpose.

As far as we are aware, there is no published report on the presence of bPI-3V infection of ruminants in the Caribbean region. The aim of this project was to estimate the prevalence of antibodies to bPI-3V in ruminants of Grenada.

\section{Materials and Methods}

\subsection{Collection of Sample}

Peripheral blood from a total of 180 ruminants: 60 sheep, 60 goats and 60 cattle were collected randomly from all six parishes of the country in 2014. Serum was separated by centrifugation at $1500 \mathrm{~g}$ for 15 minutes and stored at $-80^{\circ} \mathrm{C}$ until it was analyzed using ELISA. ELISA kit for the detection of antibodies to bPI-3V was obtained from IDvet Innovative Diagnostics, France. ELISA was performed following the manufacturer's instructions.

\subsection{Statistical Analysis}

The data were analyzed by the statistical methods: Fisher's exact test, using a graphpad statistical software (http://www.graphpad.com/quickcalcs/contingency2).

\section{Results}

The seroprevalence of bPI-3V in cattle, sheep and goats was $13.4 \%, 16.7 \%$ and $11.7 \%$ respectively. The results are summarized in Table 1.

\section{Discussion}

Diagnosis of bPI-3 V is difficult using clinical signs only. Diagnosis is mostly based on isolation and identification of the virus coupled with demonstration of increasing antibody titer in paired sera [27]. Hemagglutination inhibition (HI) test and virus neutralization (VN) test are tests of choice for serology, but ELISA test is more 
Table 1. Seroprevalence of parainfluenza virus type 3 in ruminants from Grenada.

\begin{tabular}{cccc}
\hline Species & Number of Samples & Positives & Percentages \\
\hline Bovine & 60 & 8 & 13.4 \\
Ovine & 60 & 10 & 16.7 \\
Caprine & 60 & 7 & 11.7 \\
Total & 180 & 15 & 8.4 \\
\hline
\end{tabular}

The prevalence of antibodies between ruminants (cattle, sheep and goats) is not statistically significant $(p>0.05)$.

rapid [1]. Assaf et al. [28] while comparing the results of HI test and ELISA, found the ELISA to be 4 - 64 times more sensitive than HI test. ELISA was used in present serology work for bPI-3V antibody detection in ruminants.

We found 13.4\% (CI \pm 8.62; 4.78\% to 22.02\%; Confidence Level: 95\%) cattle positive for antibodies to bPI$3 \mathrm{~V}$. A great variation in seroprevalence of antibodies for bPI-3V has been reported in cattle from various countries of the world. In the USA seroprevalence ranged from medium (53\%) to high (95\%) in different states [5], high seroprevalence (97.5\% to 100\%) in Central and South Western France [20]. Peter and Lori [10] found a very high (93.9\%) seroprevalence in cattle in Saskatchewan and Alberta; Sakhaee et al. [11] report 100\% seropositivity in dairy herds of Iran, where as in another study in Iran Ezzi et al. [12] report 95\% seropositivity. In Mexico 75\% seropositivity was reported [16]. Moderate seropositivity (50\% to 70\%) has been reported from Turkey [7] [8], North-Western Nigeria [6], Lithuania [13], and Soudi Arabia [13] [14]. Reports of low prevalence of antibodies to bPI-3V in cattle are scanty. However, similar to our findings of low seroprevalence, Mahajan et al. [9] found 20.0\% seropositivity in dairy cattle of Punjab, India. The variation in the seropositivity may be because of the ubiquitous nature of the virus [29] and significant difference in weather in various countries of the world [12].

The result of our study on seroprevalence in small ruminants showed antibodies to bPI-3V in sheep 16.7\%; (CI \pm 9.44; 7.26\% to $26.14 \%$; $\mathrm{CL}: 95 \%$ ) and in goats $11.7 \%$ (CI \pm 8.13 ; $3.57 \%$ to $19.83 \%$; $C L$ : 95\%). There was no significant difference $(p>0.05)$ in seropositivity among these species of small ruminants. Following the first isolation of bPI-3V from sheep in 1966 [30] serological survey in many countries has shown a wide spread distribution of this virus in sheep. Jehan et al. [21] on isolation and characterization of bPI-3 virus from sheep and goats in Egypt opined that infection in sheep was higher than that in goats. We also report higher rate of seropositivity in sheep (16.7\%) than in goats (11.7\%). However, Yesilbag and Gungor [23] reported in Turkey a lower prevalence of antibodies to bPI-3V in sheep (8.8\%) than in goats (13.2\%).

None of the literature reviewed investigated all three ruminants: cattle, sheep and goats in one area at the same time. We examined antibodies to bPI-3V simultaneously in cattle, sheep and goats in Grenada and found low level of seropositivity in all three ruminant species. Ruminants in Grenada are not vaccinated against bPI$3 \mathrm{~V}$, thus, presence of antibodies to bPI-3V indicates exposure of bPI-3 virus. There is evidence of transmission of this virus between cattle and sheep and goats [27]. Grenadian famers practice housing of various livestock species in close proximity exposing them to potential cross infection.

\section{Conclusion and Recommendation}

This is the first report on the seroprevalence of bPI-3V in ruminants in Grenada. Further research to find out the exposure of ruminants in Grenada with other respiratory viruses is suggested.

\section{Acknowledgements}

This research was supported by Small Research Grant Initiative (SRGI \# 14006) from the St. George’s University, Grenada (West Indies). Logistic support from Dr. S. Kumthekar and Mr. G. Stratton is sincerely acknowledged.

\section{Competing Interest}

The authors declare that there is no competing interest. 


\section{References}

[1] Ellis, J.A. (2010) Bovine Parainfluenza-3 Virus. Veterinary Clinics of North America: Food Animal Practice, 26, 575593. http://dx.doi.org/10.1016/j.cvfa.2010.08.002

[2] Shibuta, H., Kanda, T., Adachi, A. and Yogo, Y. (1979) Characterization of Bovine Parainfluenza Virus Type 3. Microbiology and Immunology, 23, 617-628. http://dx.doi.org/10.1111/j.1348-0421.1979.tb00502.x

[3] Harwood, P.F., Gravel, L.J. and Mahony, T.J. (1959) Identification of Two Distinct Bovine Parainfluenza Virus Type 3 Genotypes. Journal of General Virology, 89, 1643-1648. http://dx.doi.org/10.1099/vir.0.2008/000026-0

[4] Hoerlein, A.B., Mansfield, M.E., Abinati, F.R. and Huebner, R.J. (1959) Studies of Shipping Fever in Cattle. 1. Parainfluenza 3 Virus Antibodies in Breeder Calves. Journal of the American Veterinary Medical Association, 135, 153-160.

[5] Abinanti, F.R., Hoerlein, A.B., Watson, R.L. and Huebner, R.J. (1961) Serologic Studies of Myxovirus Parainfluenza 3 in Cattle and the Prevalence of Antibodies in Bovines. The Journal of Immunology, 86, 505-511.

[6] Ibu, O.J., Salihu, E.A., Abechi, M.A., Aba-Adulugba, E.P. and Okewu, M. (2005) Activity of Bovine Parainfluenza Type 3 Virus in North Eastern Nigeria-A Short Communication. Sokoto Journal of Veterinary Sciences, 6, 20-23.

[7] Yesibag, K. and Gungor, B. (2008) Seroprevalence of Bovine Respiratory Viruses in North-Western Turkey. Tropical Animal Health and Production, 40, 55-60. http://dx.doi.org/10.1007/s11250-007-9053-X

[8] Yavru, S., Simesek, A., Yapkic, O. and Kale, M. (2005) Serological Evaluation of Viral Infections in Bovine Respiratory Tract. Acta Veterinaria (Beograd), 55, 219-226. http://dx.doi.org/10.2298/AVB0503219Y

[9] Mahajan, V., Leishangthem, G.D., Filia, G., Sidhu, P.K. and Singh, A. (2015) Seroprevalence of Bovine Respiratory Tract Infections in Cattle from Dairy Farms of Punjab, India. AperitoJournal of bacteriology,Virology and Parasitology, 2, 1-5.

[10] Peter, J.K.D. and Lori, E.H. (1990) Prevalence of Antibodies to Infectious Rhinotracheitis, Parainfoueza 3, Bovine Respiratory Syncytial, and Bovine Viral Diarrhea Viruses in Cattle in Saskatchewan and Alberta. The Canadian Veterinary Journal, 31, 815-820.

[11] Sakhaee, E., Khalili, M. and Kazeminia, S. (2009) Serological Study of Bovine Viral Respiratory Diseases in Dairy Herds in Kerman Province, Iran. Iranian Journal of Veterinary Research, Shiraz University, 10, 49-53.

[12] Ezzi, A., Hatami, A., Bakhshesh, M., Shoukri, M.R. and Gharanghozloyan, M. (2013) Serological Study of Bovine Herpesvirus Type 1 and Parainfluenza Type 3 in Cow Farms of Qazvin Province Based on Different Ages and Season. Archives of Razi Institute, 68, 53-57.

[13] Kristina, K., Salomskas, A., Jace Vicius, E., Petkevicius, S., Lelesius, R., Mockeliunas, R. and Liutkeviciene, V. (2009) Prevalence of Bovine Parainfluenza 3 and Respiratory Syncytial Virus in Lithuanian Cattle. Veterinarja Ire Zooteccknika, 47, 69.

[14] Mahmoud, M.A. and Allam, A.M. (2013) Serprevalence of Bovine Diarrhea Virus (BVDV), Bovine Herpes Virus Type 1 (BHV-1), Parainfluenza Type 3 Virus (PI-3V) and Bovine Syncytial Virus (BRSV) among Non Vaccinated Cattle. Global Veterinaria, 10, 348-353.

[15] Yousef, M.R., El Fetah Mahmoud, M.A., Mohamed, S. and Hamad Al-Blowi, M. (2013) Seroprevalence of Some Bovine Respiratory Diseases among Non Vaccinated Cattle in South Arabia. Veterinary World, 6, 1-4. http://dx.doi.org/10.5455/vetworld.2013.1-4

[16] Victor, M.S., Onuma, M., Aguilar, R. and Murakami, Y. (1983) Prevalence of Bovine Herpes Virus-1, Parainfluenza-3, Bovine Rotavirus, Bovine Viral Diarrhea, Bovine Adenovirus-7, Bovine Leukemia Virus and Bluetongue Virus Antibodies in Cattle in Mexico. Japanese Journal of Veterinary Research, 31, 125-132.

[17] Jose Segura, C., Daniel Fegueroa, C.H., Luis Garcia, M. and Alfonso Pescador, R. (2013) Parainfluenza-3 and Bovine Respiratory Syncytial Virus: Intraherd Coorelation Adjusted for Sensitivity and Specificity. Revista MVZ Córdoba, 18, 3807-3811.

[18] Roberto, C.G., da Silva Andreza, A., Danilo, O.L.F., Julio, S.M., Edviges, M.P. and Adriano, D. (2011) Detection of Serum Antibodies to Parainflueza Type 3 Virus, Respiratory Syncytial Virus, Bovine Viral Diarrhea Virus and Herpes Virus Type 1 in Sheep in Region of Botucatu, Sao Paulo, Brazil. Journal of Veterinary Medicine and Animal Health, 3 , $1-5$.

[19] Giangaspero, M., Vacirca, G., Vanopdenbosch, E. and Biondee, H. (1992) Epidemiological Survey on Virus Diseases of Cattle in North West Syria. Tropicultura, 10, 55-57.

[20] Valarcher, J.F. and Hogghund, S. (2006) Viral Respiratory Infections in Cattle. World Buiatrics Congress 2006, Nice, 15-19 October 2006.

[21] Jehan, A.M., Gafer Hussein, H.A. and Reda, I.M. (2009) Isolation and Characterization of PI-3 Virus from Sheep and Goats. International Journal of Virology, 5, 28-35. http://dx.doi.org/10.3923/ijv.2009.28.35 
[22] Adriana, A., Dragos, A., Cristian, R. and Gheorghe, S. (2015) Detection of Parainfluenza Type 3 Virus Antigen in Goats. Bulletin of the University of Agricultural Sciences and Veterinary Medicine, 72, 27-29.

[23] Yesilbag, K. and Gungor, B. (2008) Antibody Prevalence against Respiratory Viruses in Sheep and Goats in NorthWestern Turkey. Tropical Animal Health and Production, 41, 421-425. http://dx.doi.org/10.3923/ijv.2009.28.35

[24] Ataseven, V.S., Basaran, Z., Yilmaz, V. and Dagalp, S.B. (2010) Seroprevalence of Parainfluenza Virus-3 (PI-3V) and Bovine Herpes Virus (BHV-1) Infections in Goats of Van Province (Turkey). Yuzuncu yil Universitesi Veteriner Fakultesi Dergisi, 21, 7-9.

[25] Lamontagne, J.P., Descoteaux, J.P. and Roy, R. (1985) Epizootiological Survey of Parainfluenza-3, Reovirus-3, Respiratory Syncytial and Infectious Bovine Rhinotracheitis Viral Antibodies in Sheep and Goat Flocks in Quebec. Canadian Journal of Comparative Medicine, 49, 424-428.

[26] Giangaspero, M., Savini, G., Orusa, R., Osawa, T. and Harasawa, R. (2013) Prevalence of Antibodies against Parainfluenza Virus Type 3, Respiratory Syncytial Virus and Bovine Herpes Virus Type 1 in Sheep from Northern Prefectures of Japan. Veterinaria Italiana, 49, 285-289.

[27] Elankumaran, S. (2013) Bovine Parainfluenza Virus 3. In: Munir, M., Ed., Mononegaviruses of Veterinary Importance: Volume 1: Pathobiology and Molecular Diagnosis, CABI Publishing, Wallingford, 117-118. http://dx.doi.org/10.1079/9781780641799.0117

[28] Assaf, R., Montpetit, C. and Marsolais, G. (1983) Serology of Bovine Parainfluenza Virus Type 3: Comparison of the Enzyme Linked Immunosorbent Assay and Hemagglutination Inhibition. Canadian Journal of Comparative Medicine, 47, 140-142.

[29] Bryson, D.G. (1990) Parainfluenza 3 Virus in Cattle. In: Dinter, Z. and Moein, B., Eds., Virus Infection in Ruminants, Vol. 3, Elsevier, Amsterdam, 319-333. http://dx.doi.org/10.1016/B978-0-444-87312-5.50047-3

[30] Hore, D.E. (1966) Isolation of Ovine Strain of PI-3 Virus Serologically Related to Type 3. Veterinary Record, 80, 2627. http://dx.doi.org/10.1136/vr.80.1.26 